Prepared for the U.S. Department of Energy

under Contract DE-AC05-76RL01830

\title{
Characterization of Material from Wells 299-W10-35 (C7573) and 299-W14-74 (C7024)
}

$\begin{array}{ll}\text { F Tilton } & \text { CC Bovaird } \\ \text { DM Wellman } & \text { SC Strandquist }\end{array}$

July 2011

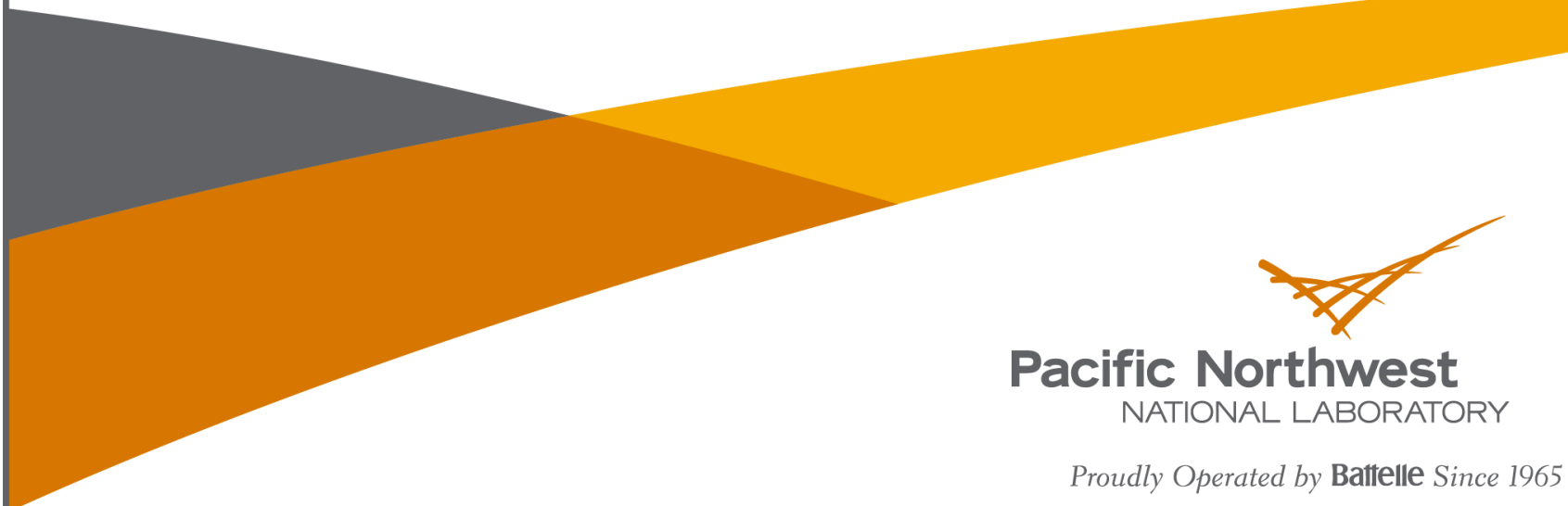





\title{
DISCLAIMER
}

This report was prepared as an account of work sponsored by an agency of the United States Government. Neither the United States Government nor any agency thereof, nor Battelle Memorial Institute, nor any of their employees, makes any warranty, express or implied, or assumes any legal liability or responsibility for the accuracy, completeness, or usefulness of any information, apparatus, product, or process disclosed, or represents that its use would not infringe privately owned rights. Reference herein to any specific commercial product, process, or service by trade name, trademark, manufacturer, or otherwise does not necessarily constitute or imply its endorsement, recommendation, or favoring by the United States Government or any agency thereof, or Battelle Memorial Institute. The views and opinions of authors expressed herein do not necessarily state or reflect those of the United States Government or any agency thereof.

\author{
PACIFIC NORTHWEST NATIONAL LABORATORY \\ operated by \\ BATTELLE \\ for the \\ UNITED STATES DEPARTMENT OF ENERGY \\ under Contract DE-AC05-76RL01830 \\ Printed in the United States of America
Available to DOE and DOE contractors from the Office of Scientific and Technical Information, P.O. Box 62, Oak Ridge, TN 37831-0062; ph: (865) 576-8401 fax: (865) 576-5728
email: reports@adonis.osti.gov

Available to the public from the National Technical Information Service 5301 Shawnee Rd., Alexandria, VA 22312

ph: (800) 553-NTIS (6847)

email: orders@ntis.gov <http://www.ntis.gov/about/form.aspx>

Online ordering: http://www.ntis.gov

This document was printed on recycled paper. 


\title{
Characterization of Material from Wells 299-W10-35 (C7573) and 299-W14-74 (C7024)
}

\author{
F Tilton \\ CC Bovaird \\ DM Wellman \\ SC Strandquist
}

July 2011

Prepared for

the U.S. Department of Energy

under Contract DE-AC05-76RL01830

Pacific Northwest National Laboratory

Richland, Washington 99352 



\section{Acronyms and Abbreviations}

$\begin{array}{ll}\text { bgs } & \text { below ground surface } \\ \text { CFR } & \text { Code of Federal Regulations } \\ \text { CHPRC } & \text { CH2M HILL Plateau Remediation Company } \\ \text { DNA } & \text { deoxyribonucleic acid } \\ \text { DOE } & \text { U.S. Department of Energy } \\ \text { EDS } & \text { energy dispersive spectrometry } \\ \text { PCR } & \text { polymer chain reaction } \\ \text { PNNL } & \text { Pacific Northwest National Laboratory } \\ \text { QA } & \text { quality assurance } \\ \text { SEM } & \text { scanning electron microscopy }\end{array}$





\section{Contents}

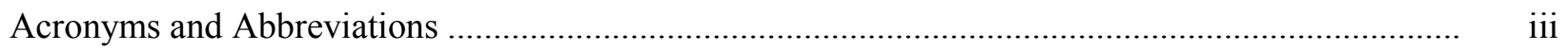

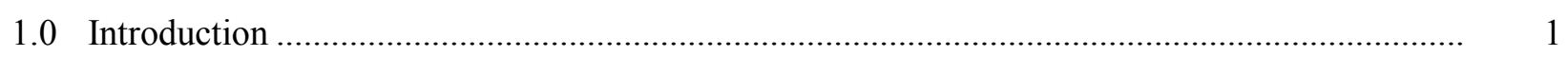

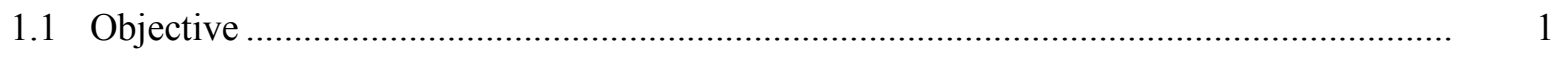

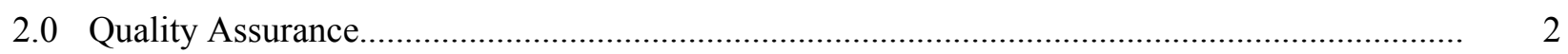

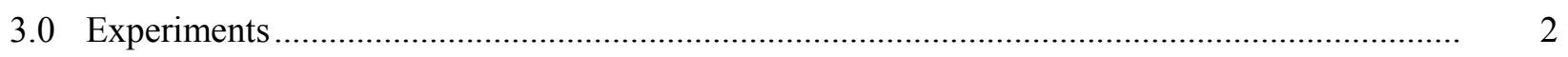

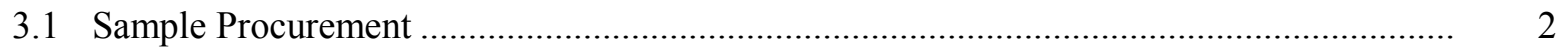

3.2 Scanning Electron Microscopy - Energy Dispersive Spectrometry ................................. 3

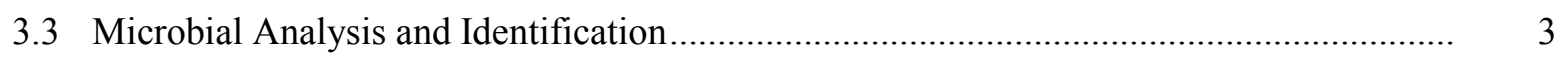

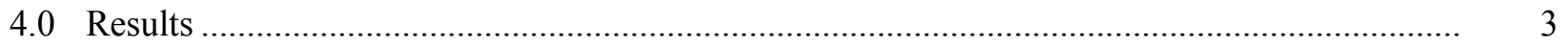

4.1 Scanning Electron Microscopy - Energy Dispersive Spectrometry ................................. 3

4.2 Chemical Sample Analysis: Chemical Digestion and Inductively Coupled Plasma

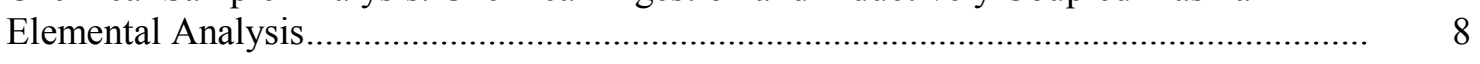

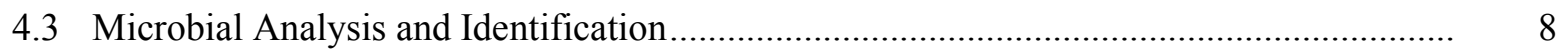

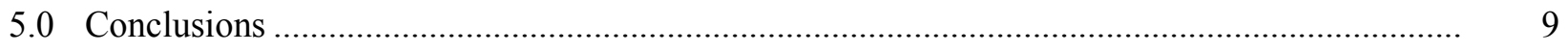

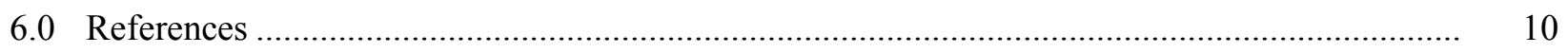

\section{Figures}

1 Photo of well screen taken from video of 299-W10-35, left and 299-W14-74, right................. 1

2 SEM Image of Sample 299-W10-35 Taken at $15 \mathrm{keV}$ and 500x Magnification........................ 4

3 EDS Spectrum for Sample 299-W10-35 at $15 \mathrm{keV}$............................................................ 5

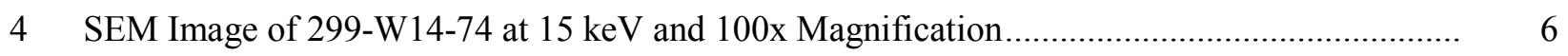

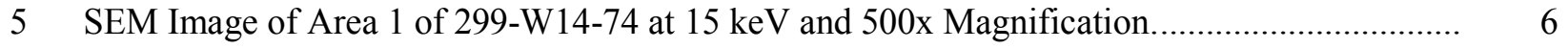

$6 \quad$ EDS Spectrum of Area 1 of 299-W14-74 at $15 \mathrm{keV}$.......................................................... 7

7 SEM image of Area 2 of 299-W14-74 at $15 \mathrm{keV}$ and 500x Magnification ................................ 7

8 EDS Spectrum of Area 2 of 299-W14-74 at $15 \mathrm{keV}$............................................................. 8

\section{Tables}

1 Chemical and Physical Parameters Associated With Groundwater Samples from Wells 299-W10-35 and 299-W14-74 


\subsection{Introduction}

Extraction and injection wells 299-W10-35 (C7573) and 299-W14-74 (C7024) possess unknown material attached to the well screens (Figure 1). Both wells are located on the Hanford Site. Well 299-W10-35 (C7573) is located west of the 218-W-3A dry waste burial ground, west of Dayton Avenue, and north of $23^{\text {rd }}$ Street and has accumulated white material on the screen and in the sump. Well 299-W14-74 (C7024) is located south of $23^{\text {rd }}$ Street and east of Beloit Avenue.
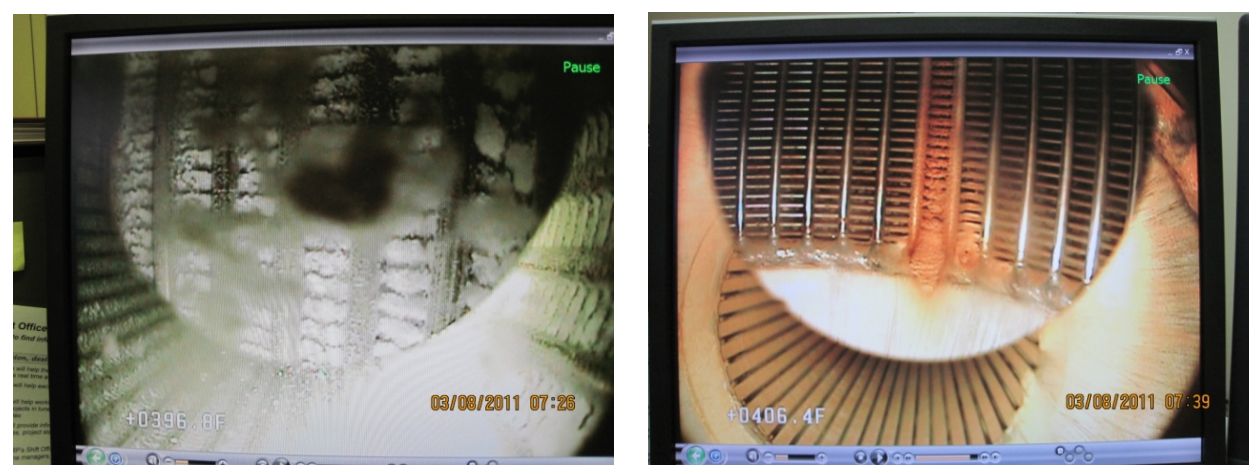

Figure 1. Photo of Well Screen Taken from Video of 299-W10-35 (C7573), Left and 299-W14-74 (C7024), Right

There are two types of material: one is reddish/orange (hypothesized to be iron-utilizing bacterial colonies) and the other is white and may or may not be biological. CH2M HILL Plateau Remediation Company (CHPRC) is conducting onsite sampling for total organic carbon, calcium carbonate, and metals. Table 1 presents chemical data for the groundwater samples associated with these materials.

\subsection{Objective}

The objective of this work was to characterize material accumulating on wells 299-W10-35 (C7573) and 299-W14-74 (C7024) to determine the type of material (i.e., chemical or biological), and if the material is biological, to identify the microorganisms present. 
Table 1. Chemical and Physical Parameters Associated with Groundwater Samples from Wells 299-W10-35 (C7573) and 299-W14-74 (C7024)

\begin{tabular}{|c|c|c|c|c|c|c|c|c|c|}
\hline Well Name & $\begin{array}{c}\text { Well } \\
\text { Number }\end{array}$ & $\begin{array}{l}\text { Total } \\
\text { Dept } \\
\mathrm{h}(\mathrm{m})\end{array}$ & $\begin{array}{c}\text { Depth to } \\
\text { Water } \\
\text { (ft) }\end{array}$ & $\begin{array}{c}\mathrm{CCl}_{4} \\
\mathrm{Max} \\
(\mathrm{ug} / \mathrm{L})\end{array}$ & $\begin{array}{c}\text { Tc-99 } \\
\text { Max } \\
\text { (pCi/L) }\end{array}$ & $\begin{array}{c}\mathrm{NO}_{3} \\
\mathrm{Max} \\
(\mathrm{ppm})\end{array}$ & $\begin{array}{c}\text { DO } \\
\text { Max } \\
(\mathrm{ug} / \mathrm{L})\end{array}$ & $\begin{array}{l}\text { Material } \\
\text { in Sump } \\
(\mathrm{ft})\end{array}$ & Notes from Videos \\
\hline 299-W10-35 & $\mathrm{C} 7573$ & 140 & 252 & 51 & 0 & 8 & 10,500 & 12.0 & $\begin{array}{l}0-260 \mathrm{ft} \text { bgs pretty clean then start to } \\
\text { see white with red clusters at joints; } \\
\text { increasing density to } 319 \mathrm{ft} \text { bgs (very } \\
\text { dense) white with yellow orange } \\
\text { material flaking off when bumped; } \\
\text { looks like a blizzard from } 319 \mathrm{ft} \text { bgs } \\
\text { - to bottom; screen is covered all the } \\
\text { way down. This well had cement } \\
\text { accidentally spilled into well } \\
\text { resulting in a } 4.5 \mathrm{ft} \text { solid in the } \\
\text { bottom of the well. }\end{array}$ \\
\hline 299-W14-74 & C7024 & 154 & 291 & 1600 & 104 & 21 & 9750 & 1.0 & $\begin{array}{l}\text { Minimal material (dark red in color) } \\
\text { on the joints from TOC to } \sim 341 \mathrm{ft} \\
\text { bgs, then increasing clusters } \\
\text { adhering to the screen sections to } \\
\sim 353 \mathrm{ft} \text { bgs, then dense coverage to } \\
\text { the sump. }\end{array}$ \\
\hline
\end{tabular}

\subsection{Quality Assurance}

Work delineated in this plan was conducted under the control of two quality assurance plans:

- PNNL-17346, Rev. 4, The CHPRC Groundwater and Technical Integration Support Projects Quality Assurance Management Plan

- PNNL-SA-40114, Rev. 1, Quality Assurance Plan for Laboratory Analyses.

The U.S. Department of Energy (DOE) has established via the Pacific Northwest National Laboratory (PNNL) Management and Operating Contract DE-AC05-76RL01830 that DOE Order 414.1C, "Quality Assurance," is the basic quality requirement. PNNL recognizes that Part 10 of the Code of Federal Regulations (CFR) 830, Subpart A, "Quality Assurance Requirements," is a federal regulation applicable to DOE facilities. The Battelle - Pacific Northwest Division has chosen to implement a single Quality Assurance (QA) Program for work that addresses the requirements of DOE Order 414.1C and 10 CFR 830, Subpart A. The identified QA plans meet the requirements established in the order and regulation.

\subsection{Experiments}

\subsection{Sample Procurement}

Samples were collected in new, sterile sample vials at a minimum total volume of $150 \mathrm{~mL}$, frozen immediately upon collection, and maintained as frozen samples during transfer to CHPRC staff for scanning electron microscopy (SEM), chemical analysis, and microbial analysis and identification by PNNL scientists. 


\subsection{Scanning Electron Microscopy - Energy Dispersive Spectrometry}

SEM-energy dispersive spectrometry (EDS) was used to evaluate the structure and approximate chemical composition of the material. Photomicrographs of the materials were obtained by using a SEM JEOL 840 equipped with a Robinson 6.0 backscatter detector. The beam conditions were $15 \mathrm{KeV}$ acceleration with a $1 \mathrm{nA}$ beam current. The samples were mounted on an aluminum plate using double-sided tape and palladium-coated under a vacuum. The palladium coat provides a conductive path for the electrons and helps secure the particles. Images were acquired using GATAN DM software version 3.2 (1996).

An Oxford ISIS 300 series EDS was used to determine chemical composition. EDS spectra were stored electronically using Oxford ISIS 300 version 3.2 software. An EDS spectrum represents the chemical composition of a particle found within a sample. While not all particles are counted for the same live-/dead-time period, a typical EDS spectrum was counted for 100 seconds with $30 \%$ dead time.

\subsection{Microbial Analysis and Identification}

Commercially available kits (Mo Bio PowerWater ${ }^{\circledR}$ DNA Isolation Kit 14900-50-NF) were used to isolate environmental deoxyribonucleic acid (DNA) from the samples of interest for genomic assessment. DNA was collected by lysing the microorganisms through a combination of chemical and mechanical force against specialized beads following manufacturer instructions. DNA was released from the lysed cells and bound to a silica spin filter. The filter was washed, and the DNA was recovered in a certified DNA-free Tris buffer (Mo Bio doc \#1490).

After the sample DNA was isolated, 16s rRNA DNA fragments were amplified using well established polymerase chain reaction (PCR) primers that were anchored in both a conserved and variable region of gene, thereby allowing eventual species elucidation of the amplified DNA fragments. The PCR amplicons were then cloned using commercially available kits and methods (TOPO TA Cloning Kit [Invitrogen]). Following cloning, the competent cells were plated in both high and low densities on a selective media containing both $50 \mu \mathrm{g} / \mathrm{ml}$ ampicillian and kanamyacin. The plates were held at $37^{\circ} \mathrm{C}$ overnight and the presence or absence of successful clones was visually determined.

\subsection{Results}

This section describes the results from the SEM-EDS, chemical sample analysis, and microbial analysis and identification experiments.

\subsection{Scanning Electron Microscopy - Energy Dispersive Spectrometry}

SEM samples were prepared from wells 299-W10-35 (C7573 I-001) and 299-W14-74 (C7024 I-001) by thawing the frozen mixture and then drying the precipitate. The 299-W10-35 well sample was a white precipitate. The 299-W14-74 well sample contained a mixture of white and red particles. 
The particles in samples from well 299-W10-35 were found to be homogeneous. Figure 2 is a SEM image of well 299-W10-35 taken at a $15 \mathrm{keV}$ accelerating voltage at x500 magnification. The morphological structure of the particle is not biological. An EDS spectrum was created from the area within the white box in Figure 2; the EDS spectrum is presented in Figure 3. Results of the EDS analysis suggest a calcium carbonate precipitate, with the weight percentages quantified as $34.74 \%$ $\mathrm{Ca}, 56.65 \% \mathrm{O}$, and $4 \% \mathrm{C}$.

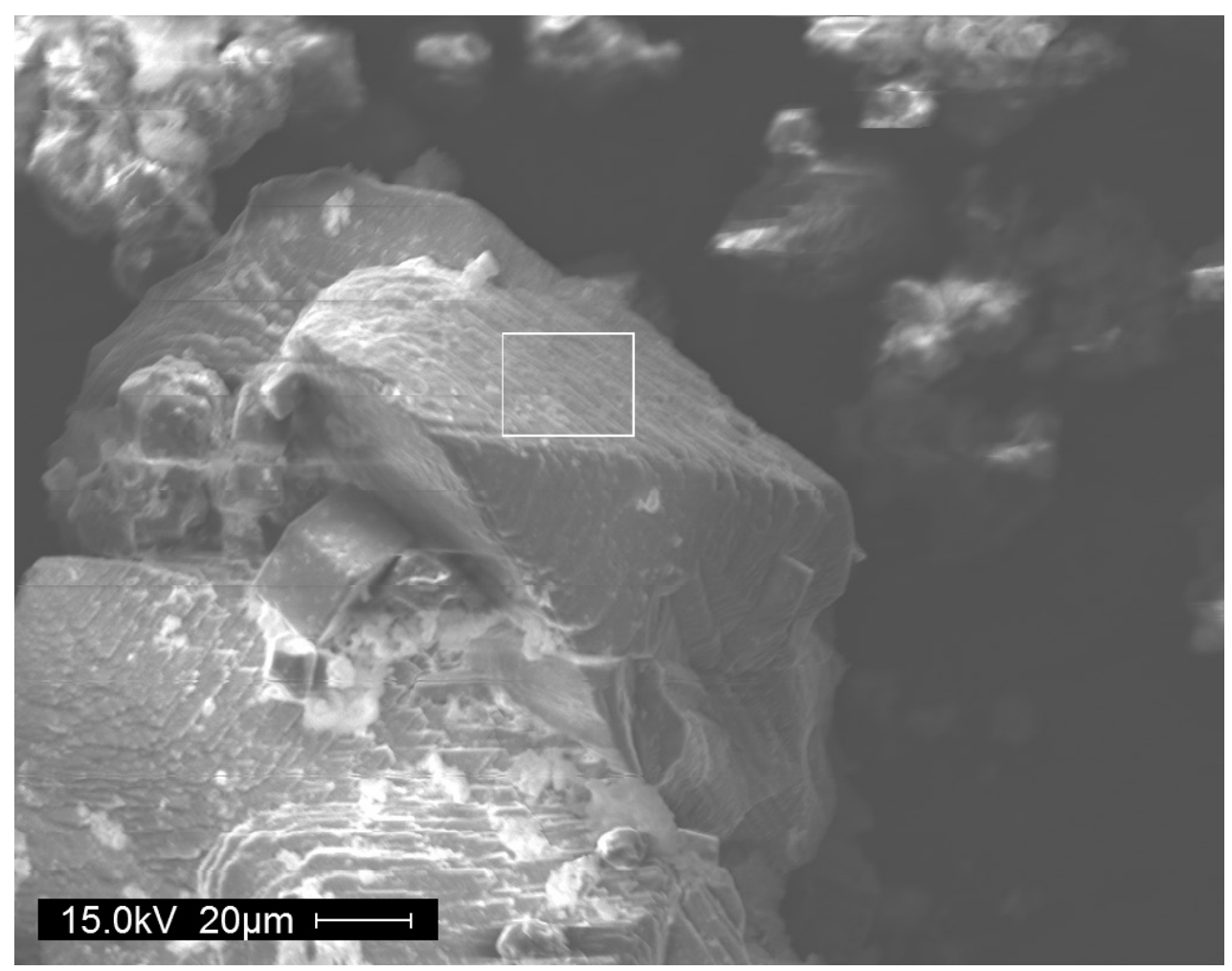

Figure 2. SEM Image of Well 299-W10-35 Sample Taken at $15 \mathrm{keV}$ and 500x Magnification 


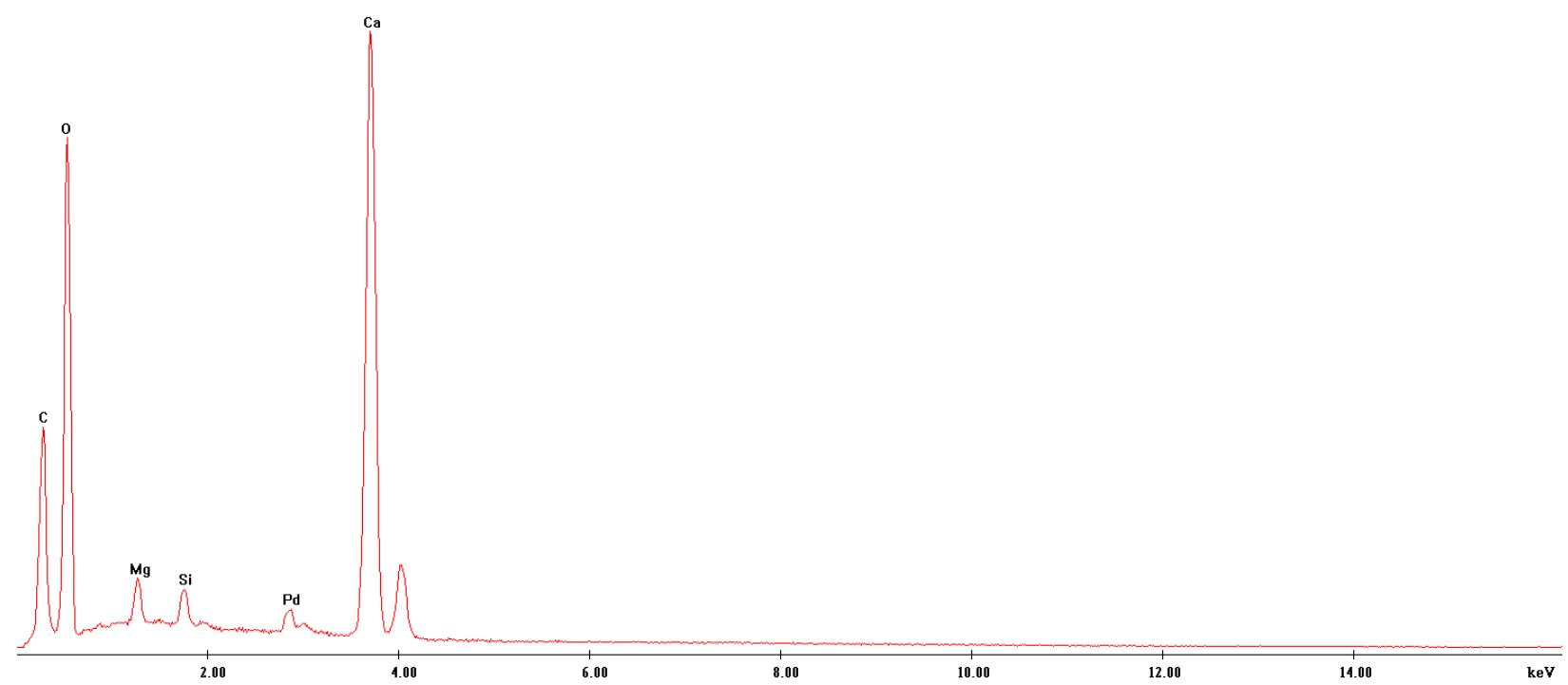

Figure 3. EDS Spectrum for 299-W10-35 Well Sample at $15 \mathrm{keV}$

The SEM image of well 299-W14-74 is presented in Figure 4. The image confirmed the presence of two morphologically distinct particles: a smooth particle found in area 1 and a rough particle found in area 2. SEM-EDS analysis was performed on both particles. The SEM image in Figure 5 is of the particle in area 1 taken at 500x magnification. EDS analysis was performed on the area inside the box (Figure 6). The spectrum indicates that the structure is a silicon-oxide compound, which are most likely sand particles. 


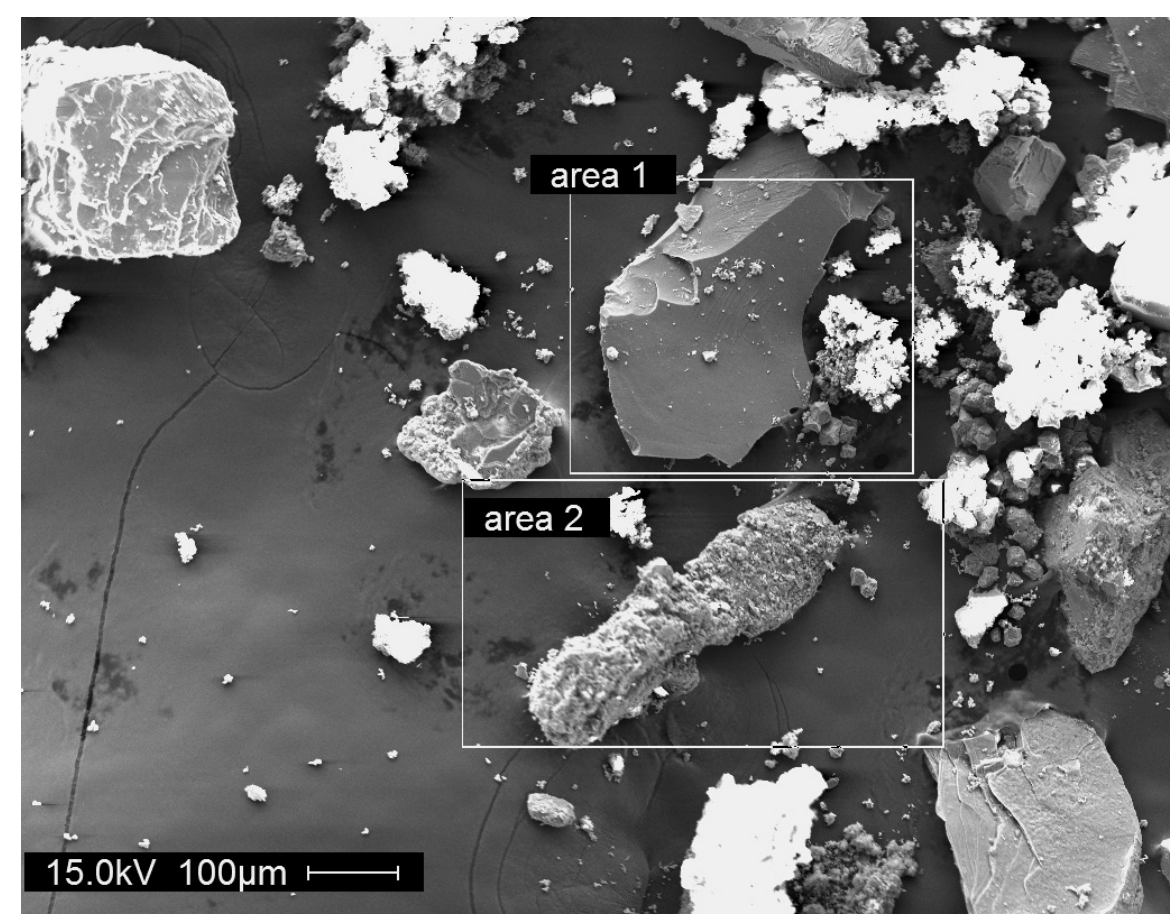

Figure 4. SEM Image of Well 299-W14-74 at $15 \mathrm{keV}$ and 100x Magnification

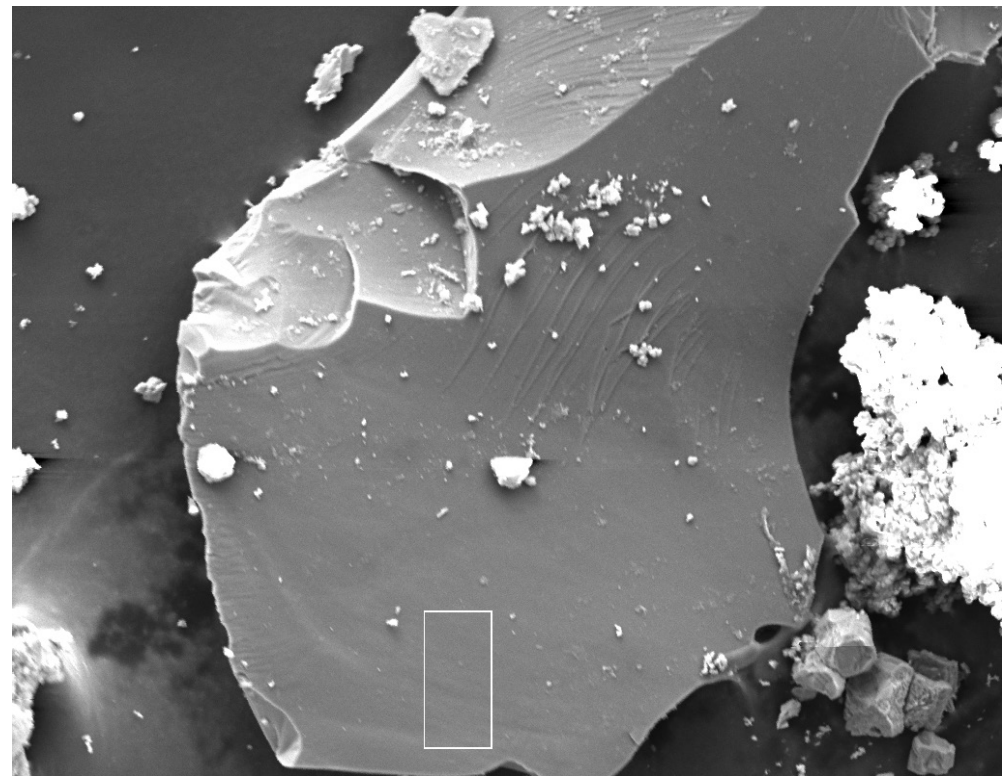

Figure 5. SEM Image of Area 1 of Well 299-W14-74 at $15 \mathrm{keV}$ and 500x Magnification 


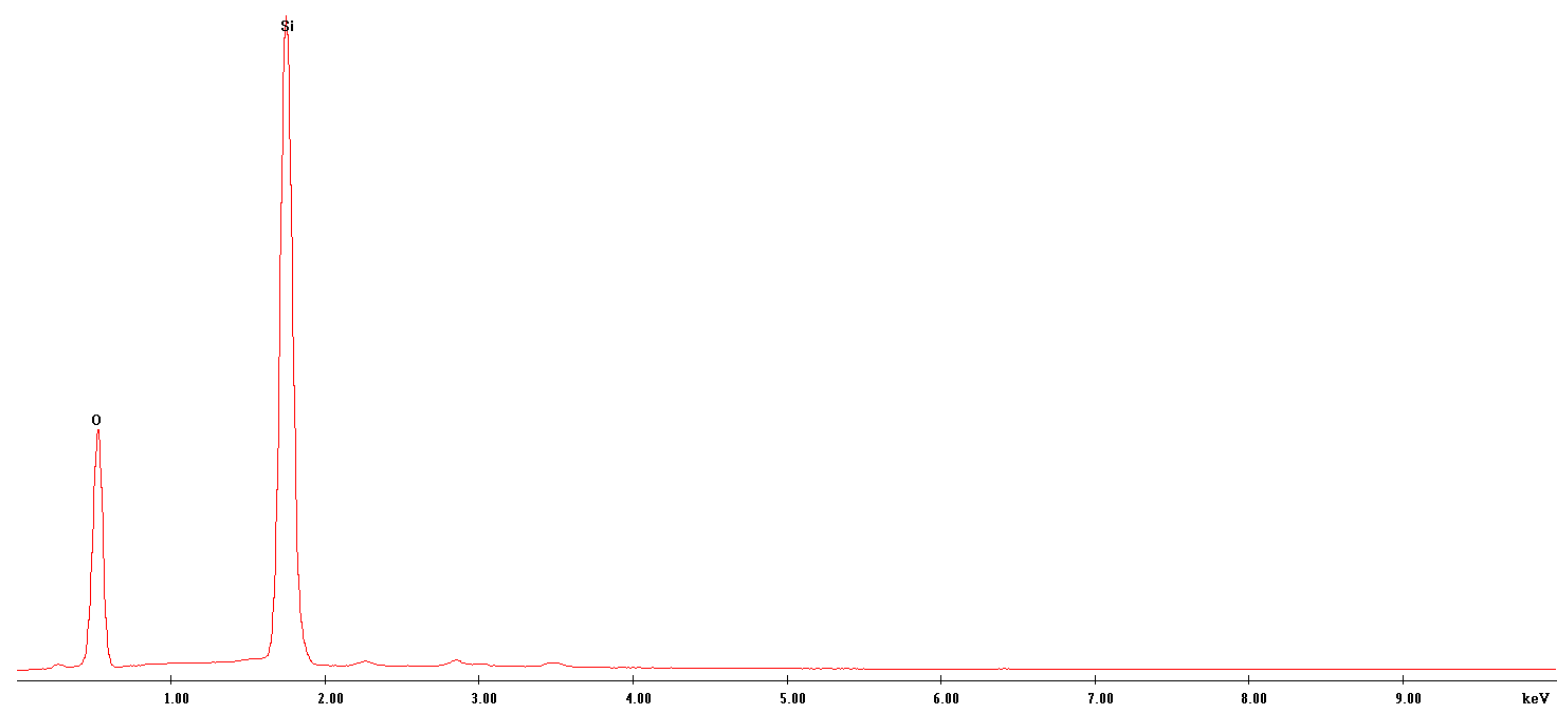

Figure 6. EDS Spectrum of Area 1 of Well 299-W14-74 at $15 \mathrm{keV}$

Figure 7 is a SEM image from area 2 of well 299-W14-74 at 500x magnification. EDS analysis (Figure 8) was performed on the area indicated by the white arrow. The results from the EDS analysis indicate the particle potentially is an iron-hydroxide coating on an aluminosilicate. The weight percentages were quantified as $22.82 \% \mathrm{Fe}, 12.94 \% \mathrm{Si}, 26.88 \% \mathrm{O}$, and $4.44 \% \mathrm{Al}$. Additionally, carbon and chlorine were also identified as major elements, with $9.58 \% \mathrm{Cl}$ and $6.74 \% \mathrm{Cl}$ quantified. Due to the high concentration of $\mathrm{CCl}_{4}$ in the well water $(1600 \mu \mathrm{g} / \mathrm{L}$ at $154 \mathrm{~m})$, this potentially could be due to sorption of $\mathrm{CCl}_{4}$ on the particle surface.

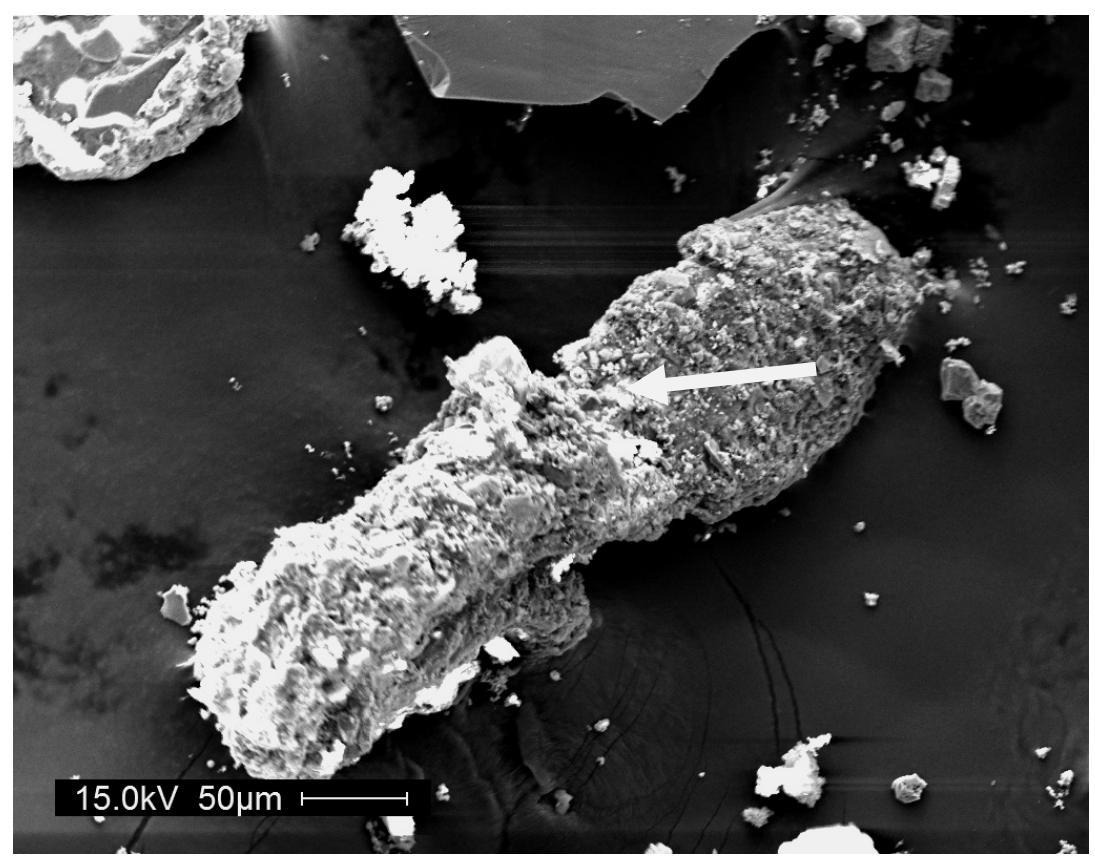

Figure 7. SEM image of Area 2 of Well 299-W14-74 at $15 \mathrm{keV}$ and 500x Magnification 


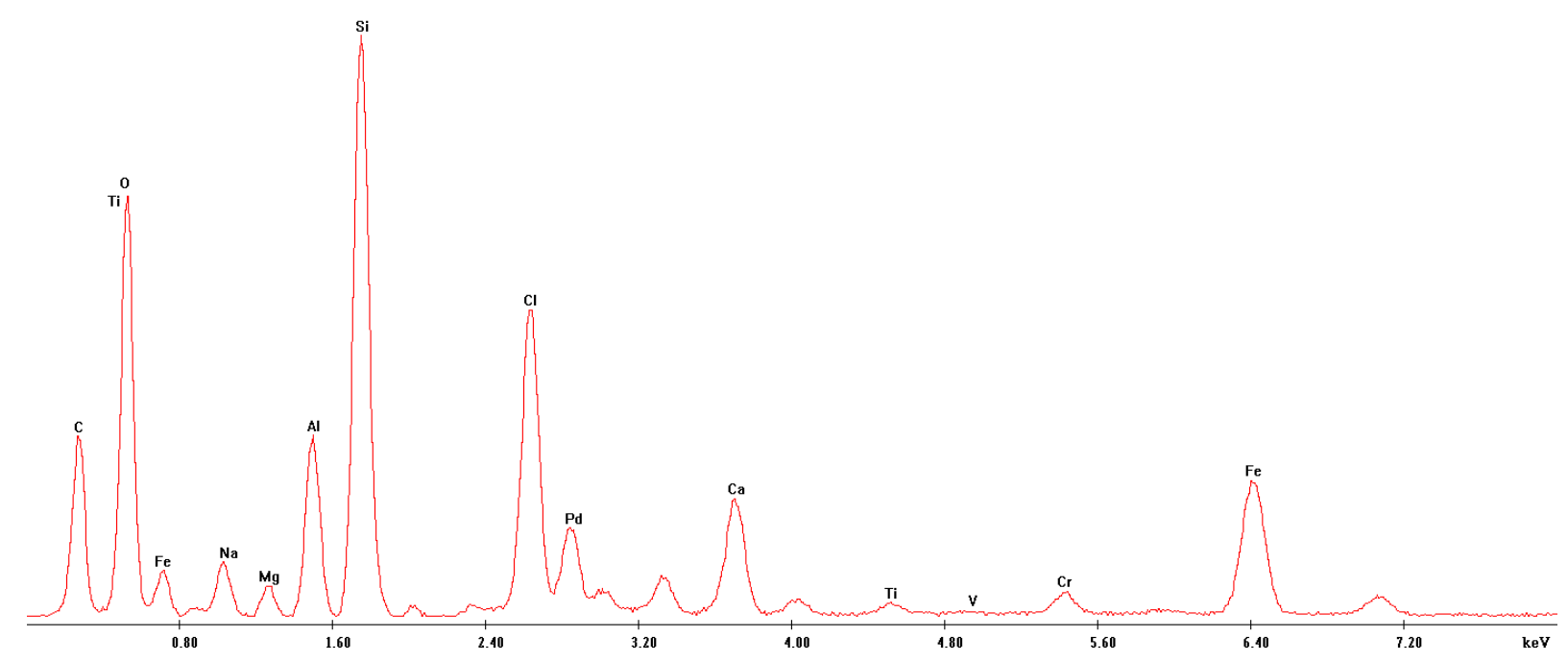

Figure 8. EDS Spectrum of Area 2 of 299-W14-74 at $15 \mathrm{keV}$

\subsection{Chemical Sample Analysis: Chemical Digestion and Inductively Coupled Plasma Elemental Analysis}

This report defers to the analysis report completed by Test America Inc. and CHPRC (dated June 19, 2011) and metals analysis conducted by the Waste Sampling and Characterization Facility (WESF) Laboratory (received June 10, 2011). ${ }^{1}$

\subsection{Microbial Analysis and Identification}

For each of the two samples, $100 \mathrm{~mL}$ of sample was placed in a separate filtration flask apparatus provided by the manufacturer (as determined by apparatus gradations). In the instance of the sample from well 299-W10-35 (i.e., white precipitate), this process necessitated the transfer of approximately $30 \mathrm{~mL}$ of solid white precipitate to the apparatus. The liquid was then drawn through a 0.22 micron filter by vacuum until no liquid remained in the reservoir and the filter membrane or precipitate appeared dry. There was $\sim 30 \mathrm{ml}$ of solid material from 299-W10-35 and an obvious fine red precipitate (from well 299-W14-74) observed on the other sample collection filter. The remaining white precipitate/solid from 299-W10-35 was held over at $-80^{\circ} \mathrm{C}$ for possible precipitate-bound DNA extraction. The filters were

\footnotetext{
${ }^{1}$ Test America. 2011. Analytical Report - SDG\# SL1079. SL1079_F1E200544, prepared by M. Neely, CH2M Hill Plateau Remediation Company, Richland, Washington, and Test America Laboratories, Inc., Earth City, Montana.

WESF Laboratory. 2011. Final Result for Sample Delivery Group WSCF112260. Letter to M. Neely (CH2M Hill Plateau Remediation Company, Richland, Washington) from J. Hale (WSCF Analytical Laboratory), dated June 9, 2011.
} 
removed from the apparatus using sterile forceps and processed following manufacturer instructions (Mo Bio PowerWater ${ }^{\circledR}$ DNA Isolation Kit 14900-50-NF; MoBio doc \#1490). This resulted in $3 \mathrm{~mL}$ of purified and isolated DNA-containing water that was stored at $-80^{\circ} \mathrm{C}$ until PCR amplification and cloning the following day.

Three 50- $\mu \mathrm{L}$ PCR reactions were set up for each of the two samples. Each reaction contained $4 \mu \mathrm{L}$ of the DNA isolations described above. The universal bacteria 16S rRNA primers used in this study were 27F 5'-AGAGTTTGATCCTGGCTCAG-3' and 1492R 5'-GGTTACCTTGTTACGACTT-3' at the final concentration of $0.5 \mu \mathrm{M}$. Optimum PCR conditions for this primer pair were determined in previous studies by using the FailSafe PCR PreMix Selection Kit (Epicentre Biotechnologies). This kit contains 12 reaction premixes that consist of a buffered salt solution with the 4 dNTPs, varying quantities of $\mathrm{MgCl}_{2}$ (3-7 mM), and a patented PCR enhancer with trimethyl glycine (0-8X). The master mix, $25 \mu \mathrm{L}$ per reaction, contained $\mathrm{MgCl}_{2}$ and a 10x PCR buffer, which was supplied premade by Epicentre in the proprietary mix known as "Mix B" (previously determined optimum). MasterAmp"TM Taq DNA polymerase $(0.25 \mu \mathrm{L})$ was added to each reaction (EpiCentre Q82100). The PCR reaction series described below was used beginning with a denaturation step of 3 min at $95^{\circ} \mathrm{C}$. Each cycle of this reaction consisted of a denaturation step of $30 \mathrm{~s}$ at $95^{\circ} \mathrm{C}$, a primer annealing step of $30 \mathrm{~s}$ at a $42^{\circ} \mathrm{C}$ and an extension step of $30 \mathrm{~s}$ at $72^{\circ} \mathrm{C} ; 40$ such cycles were completed. A final 7 -min incubation at $72^{\circ} \mathrm{C}$ was performed to elongate the resulting amplicons for cloning. All three $50-\mu \mathrm{L}$ PCR reactions for the individual samples were then combined prior to cloning.

Cloning of the bacterial DNA that had been isolated and amplified was conducted using the TOPO TA Cloning Kit (Invitrogen). For each cloning reaction, $4 \mu \mathrm{L}$ of PCR reaction was added. The resultant cloning reaction was then cloned into the vector pCR2.1 using the TOPO TA Cloning Kit (Invitrogen). From each cloning reaction, $40 \mu \mathrm{L}$ and $240 \mu \mathrm{L}$ were plated out onto a prewarmed LB agar plate containing $50 \mu \mathrm{g} / \mathrm{ml}$ ampicillian and kanamyacin. Plates were incubated overnight at $37^{\circ} \mathrm{C}$ and visually inspected the following day for white colonies (indicating a successful vector insert). Upon visual inspection the following day, for both samples and all plates, there were no white colonies visible (i.e., successful vector inserts). Therefore, there was no recoverable bacterial DNA from the samples provided. This likely infers that there was not a significant presence of bacterial organisms. Given there was nothing to grow-up for sequence analysis, this task was omitted. Though unlikely, it is possible the samples were not of sufficient size given the bacterial population density or that they were not collected in a manner adequate so as to capture these rare/low abundant organisms. The possible presence of Archea and fungi using similar universal primers was not assessed.

\subsection{Conclusions}

- SEM-EDS analysis of samples from wells 299-W10-35 and 299-W14-74 indicated the specimens did not contain biological material. The precipitate in 299-W10-35 was identified as a calcium carbonate. The particles in 299-W14-74 were identified as a silicon oxide compound, and potentially an aluminosilicate with iron hydroxide and carbon tetrachloride compounds sorbed to its surface.

- No clones were obtained from either sample; therefore, it is highly unlikely that viable bacterial organisms, or their DNA, were present. 


\subsection{References}

10 CFR 830, Subpart A. “Quality Assurance Requirements.” Code of Federal Regulations, U.S. Department of Energy, Washington, D.C.

DOE Order 414.1C. 2005. “Quality Assurance.” U.S. Department of Energy, Washington, D.C.

Lane D. 1991. "16S/23S rRNA sequencing." In Nucleic Acid Techniques in Bacterial Systematics, eds. E Stackbrandt and M Goodfellow. Wiley: Chichester, United Kingdom, pp. 115-175.

PNNL-17346, Rev. 4. 2011. The CHPRC Groundwater and Technical Integration Support Projects Quality Assurance Management Plan. Pacific Northwest National Laboratory, Richland, Washington.

PNNL-SA-40114, Rev. 1. 2011. Quality Assurance Plan for Laboratory Analyses. Pacific Northwest National Laboratory, Richland, Washington. 


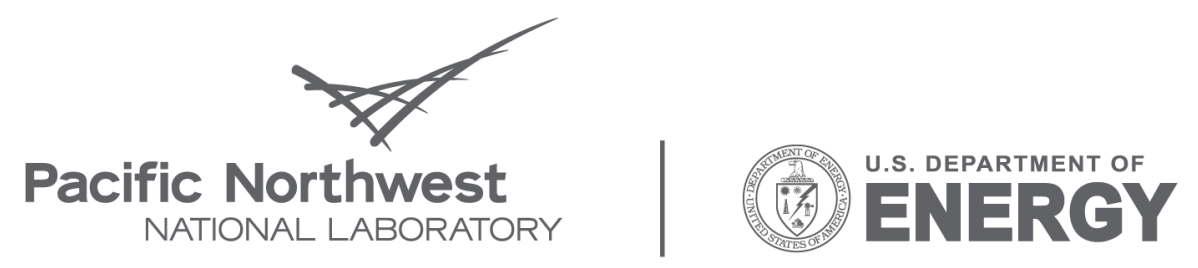

Proudly Operated by Battelle Since 1965

902 Battelle Boulevard

P.O. Box 999

Richland, WA 99352

1-888-375-PNNL (7665)

www.pnl.gov 